\title{
Conflicts in marriage laws in children: Medico-Legal and social implications
}

\author{
Gunathilaka MMAC*, Perera WNS
}

Department of Forensic Medicine, Faculty of Medicine, University of Kelaniya

\begin{abstract}
The General Marriage Registration Ordinance of Sri Lanka sets the minimum age of marriage at 18 even though there is a conflict between the Muslim Marriage and Divorce Act section 23 which has no minimum legal age of marriage and allows the children under the age of 12 to be married with the approval by Quazi court. Some other situations, law of the state and rights of childhood conflicts with the societal expectations when the child is not legally permitted to marry following consented sexual relationship. Case 1: A 16-year-old Muslimgirl was missing from the home and was found by the police when she was living with her boyfriend. She had consensual sexual relationship with the boyfriend. History revealed that she was not aware of age of marriage. Case 2: A 15-yearold Muslimgirl went missing and mother made a complaint to the police. History revealed that she had eloped with her sister's husband who had 2 children with the promise of-marrying her. When they returned home mother was in a dilemma regarding the complaint she made to the police. Law of the state has the right to protect all the citizens specially rights of the children. Discrepancy in the marriage law according to the ethnicity has created confusion allowing charge of rape in one ethnic group and not in another ethnic group. Moreover, child marriage compromises the right to education, health and employment while creating social issues of polygamous relationship and social security.
\end{abstract}

Keywords: Child marriage, marriage law, ethnic discrepancy

Received: 27 April 2019, Revised version accepted: 20 June 2019, Published: 30 June 2018. *Corresponding author: Gunathilaka MMAC, $\triangle$ Email: chaminda.gunathilaka@gmail.com iD https://orcid.org/0000-0002-8485-4550

Cite this article as: Gunathilaka MMAC, Perera WNS. Conflicts in marriage laws in children: Medico-Legal and social implications. Medico-Legal Journal of Sri Lanka, 2019;7(2):56-59. DOI: http://doi.org/10.4038/mljsl.v7i2.7400

Copyright: @ 2019 with the Medico-legal Journal of Sri Lanka.

This is an open-access article distributed under the terms of the Creative Commons Attribution 4.0 International License, which permits unrestricted use, distribution and reproduction in any medium provided the original author and source are credited.

\section{Introduction}

In Sri Lanka, $12 \%$ of girls are married before the age of 18 and $2 \%$ are married before their $15^{\text {th }}$ birthday. ${ }^{[1]}$ Sri Lanka has committed to eliminate child, early and forced marriage by 2030in line with target 5.3 of the Sustainable Development Goals. The General Marriage Registration Ordinance 1997 of Sri Lanka sets the minimum age of marriage at 18 even though there is a conflict between the Muslim Marriage and Divorce Act section 23 which has no minimum legal age of marriage and allows the children under the age of 12 to be married with the approval by Quazi court. ${ }^{[2,3]}$ Some other situations, law of the state and rights of childhood conflicts with the societal expectations when the child is not legally permitted to marry following consented sexual relationship. This paper discusses social and medico legal issues arise from the child marriage.

\section{Case report}

Case 1: A 16-year-old Muslim girl was missing from the home for about one month and found by the police while she was living with her boyfriend. She had consensual sexual relationship with the boyfriend throughout this period. History revealed that she was not aware of the age of marriage.

Case 2: A 15-year-old Muslim girl went missing and mother made a complaint to the police. History revealed that she had eloped with her sister's husband who had 2 children with the promise to marry her. When they returned home her mother was in a dilemma regarding the complaint she made to the police. She approved the marriage of her daughter considering the consequences on her elder daughter's family.

\section{Discussion \\ Definition of child marriage: Child marriage includes any legal or customary union involving a boy or girl below the age of $18 .{ }^{[4]}$ This definition is based on Article 1 of the Convention on the Rights of the Child (CRC), which defines a child as any human being below the age of 18 years. ${ }^{[4]}$}

The Universal Declaration of Human Rights provides that men and women of "full age" have the right to marry (Article 16.1) and that marriage shall 
be entered into only with the, "...free and full consent of the intending spouses". ${ }^{[4]}$

The Convention on the Elimination of all forms of Discrimination Against Women (CEDAW) further provides that the marriage of a child will have no legal effect. ${ }^{[4]}$

\section{Legal framework and implications:}

01. Relevant international treaties: Sri Lanka has ratified following conventions in this regards ${ }^{[5]}(1.1)$ Convention on the Rights of the Child (1989), a Convention ratified in 1991. (1.2) Optional Protocol to the Convention on the Rights of the Child on the sale of Children, Child Prostitution and Child Pornography (2000), a Convention ratified in 2006. (1.3) Convention on the Elimination of All Forms of Discrimination against Women (1979), a Convention ratified in 1981. (1.4) International Covenant on Economic, Social and Cultural Rights (1966), a Convention ratified in 1980. (1.5) Convention on Consent to Marriage, Minimum Age for Marriage and Registration of Marriages (1962), a Convention signed in 1962.

02. Constitutional provisions: Fundamental rights are covered under Chapter III of the Constitution of the Democratic Socialist Republic ofSri Lanka. Article 12 enshrines the right to equality, providing that: 1$)$ All persons are equal before the law and are entitled to the equal protection of the law; and (2) No citizen shall be discriminated against on the grounds of race, religion, language, caste, sex, political opinion, place of birth or any such grounds.Point 4 of the same article further states that "nothing in this Article shall prevent special provision beingmade, by law, subordinate legislation or executive action, for the advancement of women, children or disabled persons". ${ }^{[5]}$ The Constitution does not contain specific provisions regarding family and marriage.

03. Statutory law: Sri Lanka has a mixed legal system influenced by Roman-Dutch civil law, English common law and Jaffna Tamil customary law termed Thesawalami, Muslim law and even customary laws occasionally. ${ }^{[5]}$ The body of law relating to marriage consists general law, customary law and personal law ${ }^{[6]}$. Tamils are governed by the general law in most marriage-related matters. Kandyan Sinhalese can choose to be governed by the general law or their customary laws (Kandyan Law).Muslims are governed by Muslim personal law (Muslim Marriage and Divorce Act of Sri Lanka).According to the General Marriages Ordinance, Sec. 15, "no marriage shall be valid unless both parties to the marriage have completed eighteen years of age". However, Sec. 22 authorizes parents (or the guardian in the absence of parents) to consent to a marriage involving a minor. ${ }^{[2]}$
04. Customary/religious/traditional frameworks: One of the most contested issues in the debate around reform of the Muslim Marriage and Divorce Act (MMDA) which was drafted in 1951 has been with regard to increasing the minimum age of marriage for Muslims. While legal reforms in 1997 increased the minimum age of marriage to 18 years for all citizens except Muslims, the MMDA does not stipulate an age of marriage. The minimum age at which a Muslim girl or boy can get married under the MMDA is not 12 years; as per Section 23 of the Act, a girl below 12 can be given in marriage with the authorisation of a Quazi judge. ${ }^{[3]}$ Hence, the minimum age of marriage for Sri Lankan Muslims is technically zero. Although the MMDA emphasizes the importance of registering marriages, it also says that the validity or invalidity of a marriage does not depend on registration. This means that even unregistered customary marriages can also be considered valid under the law of Sri Lanka.

05. Provisions and sanctions: The offence of rape is included under Sec. 363 of the Penal Code, including specific reference to the case of a married woman over 12 years. ${ }^{[7]}$ According to penal code of Sri Lanka, section 363 (rape), a man is said to commit rape who enactment has sexual intercourse with a woman - with or without consent when she is under 16 years of age, unless the woman is his wife who is over 12 years of age and is not judicially separated from the man. Under the common law of Sri Lanka, consent of the child under the age of 16 for a sexual act is invalid and perpetrator will be charged under the law of rape. Further, state has signed the Convention on the Rights of the Child (CRC) and Convention on the Elimination of All Forms of Discrimination against Women (CEDAW) and bound to protect child rights. Discrepancy in the common law and MMDA according to the ethnicity has created confusion allowing charge of rape in one ethnic group and not in another.

Incest and Muslim law: The offence of incest is included under Sec. 364A of the Penal Code (Amendment) Act (No. 22 of 1995). According to penal code of Sri Lanka, Sec. 364A of the Penal Code (Amendment) Act (No. 22 of 1995), Incest, (1) Whoever has sexual inter-course with another, who stands towards him in any of the following enumerated degrees of relationship, that is to say (a) either party is directly descend from the other or is the adoptive parent, adoptive grandparent, adopted child or adopted grandchild of the other; or(b) the female, Is the sister of the male, either by the full or the half blood or by adoption, or is the daughter at his brother or of his sister, by the full or the half blood or by adoption, or is a descendant from either of them, or is the daughter of his wife by another 
father, or is his son's or grandson's or father's or grandfather's widow; or (c) the male, is the brother of the female either by the full or the half blood or by adoption, or is the son of her brother or sister by the full or the half blood or by adoption or is a descendant from either of them, of is the son of her husband by another mother, or is her deceased daughter's or granddaughter's or mother's or grandmother's husband,(2) The offence of incest shall not be affected or negated by reason of the existence of any defect in the legality of way relationship given in this section, such as absence of a valid marriage or adoption. In Muslim law, prohibited relationships in marriage include affinity, consanguinity and fosterage. Under Muslim law in Sri Lanka, incest is an offence.

Causes of child marriage: In all regions of the world, the causes of child marriage are complex, interrelated and tightly interwoven with social and economic circumstances and the cultural context.Gender inequality, poverty, insecurity in the face of war and conflict (protection of the child especially in disadvantage families or in crisis situations) and drop out from the schoolare some of the examples. ${ }^{[5]}{ }^{[8]}$. All the child marriages are not the decisions of the parents or the guardians, similar to these cases children themselves take independent decisions without understanding the gravity of the decision or to escape from difficult situations.

Consequences of child marriage: "Convention on the Rights of the Child" (CRC) and the "Convention on the Elimination of All Forms of Discrimination against Women" (CEDAW), endorsed that child marriage violates the right of the children for education, health, protection from violence, and protection from sexual exploitation and abuse.Globally, followings are consequences of child marriage. ${ }^{[5]}$

(1) Detriment to child development: There is considerable evidence of detriment to the child development for the child bride herself as well as the children she may bear at a young age - and to the community as a whole. ${ }^{[9,10]}$

(2) Poorer health outcome: Girls married at a young age are especially vulnerable to sexual and reproductive health problems, with potentially lifethreatening consequences. ${ }^{[10,11]}$ Married girls are in most cases expected to become pregnant immediately orsoon after marriage, and early marriage contributes to elevatedfertility rates overall.Complications in pregnancy and childbirth are the main causes of death among adolescent girls aged 15-19 in developing countries ${ }^{[12]}$. Maternal morbidity and maternal death are more likely for 15 to 19 -year-olds than for 20- to 24-year-olds, and even more likely for those who become pregnant or given birth before the age of 15 years. ${ }^{[13]}$ Adolescents aged 15-19 years are twice as likely to die during pregnancy or childbirth as women aged 20 and over; adolescents under 15 has five times more risk. ${ }^{[14]}$ Negative health consequences for a mother also negatively affect the health and survival of her newborn children.

(3) Poorer educational outcome: Early marriage very often precludes continuing education, just as additional years of education are associated with later age at marriage. According to qualitative research conducted by Plan UK in nine countries, child marriage and early pregnancy were cited as common reasons for girls not being able to continue in secondary school. ${ }^{[15]}$

(4) Higher risk of violence and abuse: Girls married too early are also more likely to experience domestic violence, abuse and forced sexual relations. Consequently, they are more vulnerable to sexually transmitted infections, including HIV. ${ }^{[11]}$

(5) Persistent poverty and (6) Missed opportunities for empowerment. In the long run, they also deprive girls in their adult lives of having more significant leverage within the family and community and the power to take decisions about their work, their health, their well-being and that of their children. ${ }^{[15]}$

\section{Conclusions}

Law of the state has the right to protect all the citizens equally and equitably specially rights of the children. The content in MMDA does not reflect or take into the account of socio-cultural and legal changes which has happened during last 60 years. Even though the cultural and religious diversity should be valued, common law protecting child rights must be respected above all. Otherwise, child marriage compromises the child's rights while creating psycho-social issues and discrepancy in law.

\section{Disclosure statement}

Conflicts of interests: The authors declare that they have no conflicts of interests.

\section{Funding: None}

\section{References}

1. Department of Census and Statistics and Ministry of Healthcare and Nutrition, Sri Lanka Demographic and Health Survey 2006-07, 2009 Available from: http://www.statistics.gov.lk/social/DHS\%2020 0607\%20FinalReport.pdf

2. The General Marriage Registration Ordinance 1997 of Sri Lanka. Sec.15, Sec.22 Available from: https://www.srilankalaw.lk > Volume-V > marriage-registration-ordinance 
3. Muslim Marriage and Divorce Act of 1951, Sec. 23. Available from: https://www. sri lankalaw.lk/Volume-V/muslim-marriage-anddivorce-act.html

4. Child Marriagein the Middle East and North Africa, United Nations Children's Fund UNICEF.https://www.unicef.org > mena > sites >unicef.org.mena > files

5. WHO, Child, early and forced marriage legislation in 37 Asia-Pacific countries. Available from: http://archive.ipu.org/ pdf/publications/child-marriage-en.pdf

6. Helplinelaw.com. Sri Lanka Family Laws Lawyers, Law Firms Lawyer, Injury, Attorney in Sri Lanka. Available from: http://www.helplinelaw.com/article/sri\%20lan $\mathrm{ka} / 167$.

7. Penal Code (Amendment) Act No 22 of 1995,Sec.363. Available from: http:// citizenslanka.org/wp-content/uploads /2016/02/Penal-Coda-_Amendment_-Act-No22-of-1995-E.pdf

8. Early marriage in Africa: Trends, harmful effects and interventions, Walker, J. A., Afr J Reprod Health (Special Edition), 2012;16(2):231-40.

9. Marrying too young: End child marriage, New York, UNFPA, 2012. Available at http://www.unfpa.org/sites/default/files/pubpdf/MarryingTooYoung.pdf, accessed 23 November 2015.

10. When the mother is a child: The impact of child marriage on the health and human rights of girls, Raj A. Arch Dis Child. 2010;95(11)9315.

11. Health consequences of child marriage in Africa, Nour NM. Emerg Infect Dis. 2006;12(11):1644-9.

12. Guidelines on preventing early pregnancy and poor reproductive outcomes among adolescents in developing countries, Geneva, World Health Organization, 2011. Available from: https:// www.who.int/immunization/hpv/target/prevent ing_early_pregnancy_and_poor_reproductive_ outcomes_who_2006.pdf

13. Maternal mortality in adolescents compared with women of other ages: Evidence from 144 countries, Nove A. Matthews Z, Neal S, Camacho AV. Lancet Glob Health. 2014;2(3):e155-64.

14. Lessons from India on delaying marriage for girls, Das Gupta, S., Mukherjee S, Singh S, Pande R, Basu S. Washington, D.C., International Center for Research on Women, 2009. Available from: https://www.icrw.org/wpcontent/uploads/2016/10/Knot-Ready-Lessonsfrom-India-on-Delaying-Marriage-for-Girls. pdf.

15. Building skills for life for adolescent girls programme: Global baseline report, Royal Tropical Institute, prepared for Plan UK by the Royal Tropical Institute, London, Plan UK, 2012. Available from: http://www.ungei.org/The -State-of-the-World-s-Girls-Learning-for-LifePlan-International-2012.pdf 